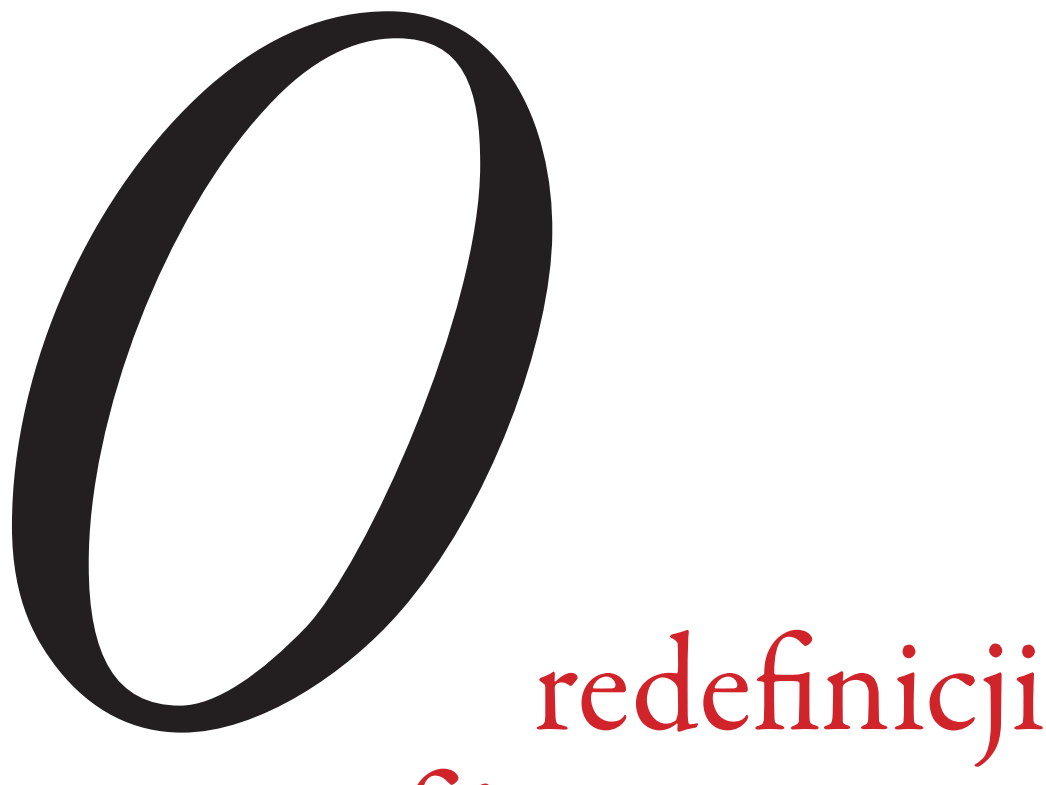

typografii

oraz nowej metodologii tworzenia komunikatów typograficznych

Sztuka Edycji 2/2016

ISSN 2084-7963 (print)

ISSN 2391-7903 (online) s. $33-40$ 
Rzadko objaśnia się, dlaczego jest ona tak istotna, podobnie zresztą jak nie mówi się, co oznacza ${ }^{1}$.

Warto dodać, że również w gronie badaczy, projektantów oraz publicystów zajmujących się problematyką czytania trudno o wyczerpujące wyjaśnienia pojęcia „czytelność”, które uwzględniałyby chociażby odmienne strategie lektury determinowane rodzajem tekstów, jak też powodów, dla których są czytane. Co jednak ciekawe, dzięki pojawieniu się nowych nośników i publikacji cyfrowych oraz towarzyszącego im dyskursu na temat przyszłości książek i czytelnictwa, można znaleźć coraz więcej wypowiedzi wyraźnie wskazujących na złożony charakter procesu czytania. Interesujący jest także kontekst, w jakim są najczęściej przywoływane. $Z$ reguły pojawiają się one jako ważna część argumentacji w sporze zwolenników książki papierowej z ich oponentami, głoszącymi wyższość nowoczesnych mediów i śmierć starych ${ }^{2}$. Jedna i druga strona, chcąc zdeprecjonować adwersarzy tego dyskursu lub przynajmniej przestrzec przed krytykowanym przez siebie nośnikiem tekstu, wskazuje jednak - nierzadko mimochodem, na marginesie - na kwestie najistotniejsze, odnoszące się do specyfiki mediów, strategii lektury czy psycho-fizjologicznych aspektów percepcji tekstu. Pojawiają się wypowiedzi, które jeszcze kilka lat temu były rzadkością, a które dziś poszerzają nasz stan wiedzy i skłaniają do refleksji nad użytkowym aspektem typografii. Paradoksalnie, dopiero zaistnienie nowych form edycji tekstu, komunikowania i sposobów percepcji doprowadziło do większego niż do tej pory skoncentrowania uwagi na specyfice procesu czytania oraz metodach służących jego ułatwieniu. Dzięki konfrontacji stanowisk, przybierającej czasem formę swoistego konkursu piękności, łatwiej można postrzegać typografię przez pryzmat celów i skutków, które ma osiągnąć komunikat typograficzny, a nie wyłącznie poświęcać uwagę tworzącym go środkom. Jeden z uczestników polemiki, amerykański dziennikarz i medioznawca - Nicholas Carr - odnosząc się do różnic między publikacjami papierowymi a cyfrowymi, będąc jednocześnie sceptykiem wobec tych ostatnich, pyta:

Jak zmienia się nasz sposób czytania? Jak zmienia się nasz sposób pisania? Jak zmienia się nasz sposób myślenia? Są to pytania, które powinniśmy bezustannie stawiać zarówno samym sobie, jak i naszym dzieciom³ ${ }^{3}$.

Chyba mało kto do tej pory zastanawiał się - w kontekście typografii - nad kwestiami związanymi z doświadczeniem czy zachowaniem użytkownika w trakcie lektury, a swoje pytania kierował do szerokiego grona odbiorców: projektantów, medioznawców, tekstologów lub redaktorów. Ten punkt widzenia zmienia dotychczasowe, tradycyjne rozumienie roli typografii i tworzy nowe aspekty badawcze. W dyskursie padają także inne ważne słowa, które z jednej strony próbują uporządkować debatę, a z drugiej wskazują na rzeczywisty cel typografii (co ciekawe, ich autorami w większości wypadków nie są projektanci). We wprowadzeniu do książki Przestrzeń pisma. Komputery, hipertekst i remediacja druku Michał Tabaczyński pisze:

Dyskusja o książce w epoce elektronicznej wcale nie powinna koncentrować się na środkach produkcji, trybie istnienia czy też dystrybucji. Tym samym to nie technologia ma być osią czy ośrodkiem tej debaty, lecz jej skutki ${ }^{4}$.

Warto tę wypowiedź - pochodzącą z innej dziedziny oraz innego czasu - porównać z definicją projektowania autorstwa prof. Andrzeja Pawłowskiego, twórcy systemu kształcenia Wzornictwa Przemysłowego w Polsce w latach sześćdziesiątych XX wieku. Projektowanie to

racjonalna działalność, której wynikiem ma być konkretny skutek. Skutek ten zostaje w procesie projektowania zaplanowany przez projektanta, natomiast plan jest realizowany przez społeczeństwo ${ }^{5}$.

I dalej:

Istotą naszych działań jest obmyślanie procesów, w których obiekty i urządzenia techniczne odgrywają jedynie rolę pomocniczą. Obmyślanie życia powinno stać się sensem projektowania ${ }^{6}$.

Ze strony tekstologów można z kolei usłyszeć zbliżony, nawet synonimiczny w duchu głos:

Autor i czytelnik mają określony cel, zamiar, przewidują określony skutek, posługując się książką jako narzędziem. Autor pragnie podzielić się swymi myślami, wynikami doświadczenia i refleksji, nakłonić do pewnego sposobu myślenia czy postępowania. Czytelnik zaś pragnie się zapoznać z jakąś dziedziną w czasie metodycznych studiów albo chce znaleźć odpowiedź na wyraźnie formułowane pytanie $[\ldots]^{7}$. 
Kluczowym w powyższych tożsamych wypowiedziach jest pojęcie „skutku”, jak również to, że obaj autorzy - mimo odmiennych kontekstów swoich wypowiedzi - zwracają uwagę na drugoplanową czy też czysto narzędziową rolę technologii w jego osiągnięciu. Określony lub oczekiwany przez nadawcę komunikatu skutek jest najważniejszy - jest rzeczywistym celem projektowania. Ten truizm w kręgu przedstawicieli dziedziny myślenia projektowego (ang. design thinking) nie jest niestety znany lub bliski sporej grupie projektantów zajmujących się typografią. Poza wskazaniem na faktyczną funkcję typografii podejście to pozwala właściwie analizować każde nowe medium komunikacyjne i oceniać jego przydatność w konkretnym kontekście komunikacyjnym. Co więcej, postulaty myślenia projektowego w typografii można odnaleźć w starszych opracowaniach, niekoniecznie bezpośrednio skierowanych do typografów. Teodor Zbierski w Semiotyce książki wyjaśnia, że:

edytor [dodajmy: i projektant - przyp. T. B.] tworzy wzór książki, biorąc pod uwagę potrzeby odbiorcy (czytelnika). Wzór produktu musi uwzględniać jego potrzeby i musi być doń przystosowany. Na przykład forma prezentacji wyników badań w książce naukowej czy też sposób podania ich w podręczniku przeznaczonym dla studentów decyduje o przyswojeniu tych treści przez odbiorcę 8 .

Wyjaśnijmy, że określenie „wzór produktu”, o którym w latach siedemdziesiątych pisał Teodor Zbierski, może obecnie odnosić się także do rodzaju nośnika.

Żeby być skutecznym, a więc osiągnąć określony cel (a przynajmniej zbliżyć się do niego) ${ }^{9}$, osoby zaangażowane w konstruowanie komunikatu typograficznego nie mogą ograniczać swoich działań wyłącznie do tworzenia przekazu wizualnego na podstawie dostrzeżenia potrzeby użytkownika oraz wygenerowania - odpowiadającego założeniom - materiału tekstowego w formie dostosowanej do treści i celu. Należy również uwzględnić - wymienione na wstępie kwestie związane z kontekstem lektury, specyfiką odbiorcy i rodzajem nośnika komunikatu. Przede wszystkim trzeba jednak doprowadzić do aktu komunikacji w taki sposób, żeby przyniósł on konkretny skutek u zdefiniowanego odbiorcy. Jest to trudne, aczkolwiek konieczne zadanie. „Komunikat książkowy to nie tylko to, co twórca napisał, lecz i to, co z niego wyczytano" 10 , a zatem wygenerowanie typografii kongenialnej jest tylko połową sukcesu. Odpowiednio zakodowany komunikat typograficzny, aby osiągnąć oczekiwany skutek, musi jeszcze dotrzeć do odbiorcy wybranym przez twórców (autora, redaktora, projektanta) kanałem komunikacyjnym. W celu uświadomienia sobie ważności tego zagadnienia warto wymienić czynniki determinujące jakość procesu czytania, rozumianego tu jako recepcja i zrozumienie tekstu o określonym znaczeniu oraz tworzenie na jego podstawie wiedzy.

Wspomniane determinanty można podzielić na dwie grupy.

1) Czynniki, na które nadawca oraz osoby współodpowiedzialne za komunikat typograficzny: autor, redaktor, tłumacz, typograf, programista, ilustrator, fotograf, mają wpływ:

- rodzaj lektury (odmiana gatunkowa),

- medium (papier, ekran, komunikat interaktywny, narracja linearna, asocjacyjna) ${ }^{11}$,

- struktura (nie-obecność ilustracji, semantyczne relacje: obraz-tekst, liczba i objętość akapitów, nie-obecność śródtytułów, przypisów, bibliografii itd.),

- język (przystępny lub hermetyczny, a także styl języka, obecność gwary, neologizmów, obcych terminów, żargonu),

- cechy fizyczne nośnika komunikatu (ciężar, format, rodzaj oprawy, zapach, objętość, kolory, światło addatywne w przypadku czytników elektronicznych lub substraktywne w przypadku publikacji drukowanych itd.).

2) Czynniki, na które nadawca oraz osoby współodpowiedzialne za komunikat typograficzny: autor, redaktor, tłumacz, typograf, programista, ilustrator, fotograf, nie mają wpływu, ale mogą je w całości lub częściowo przewidzieć:

- motywacja i intencja (motywacja zewnętrzna i wewnętrzna oraz czytelnik potencjalny, konsumpcyjny, produkcyjny $)^{12}$,

- warunki lektury (kontekst odbioru), miejsce: mieszkanie, środki transportu publicznego, biblioteka, sala przeznaczona do nauki (klasa, sala wykładowa), przestrzeń otwarta (plaża, park itd.), pozycja: siedząca (inna przy biurku, inna na ławce, w fotelu itd.), leżąca (łóżko, leżak, koc, pozycja na boku, na plecach, na brzuchu), stojąca, oświetlenie: naturalne, sztuczne (jeśli sztuczne, to zimne czy ciepłe, do tego dochodzi kwestia liczby lumenów oraz rodzaj rozproszenia światła), szum informacyjny (wszelkiego rodzaju zakłócenia: zewnętrzne i wewnętrzne, a więc takie, które mogą wyniknąć z treści lub formy książki), czas (ile czasu użytkownik jest w stanie przeznaczyć na przeczytanie konkretnego typu tekstu?, 
czynnik czasu przeznaczonego na lekturę może mieć znaczenie w odniesieniu do rodzaju tekstu lub też celu czytania (np. lektura instrukcji zajmuje zdecydowanie mniej czasu niż czytanie powieści), - specyfika odbiorcy (dojrzałość emocjonalna ${ }^{13}$, pamięć, inteligencja, skupienie, kompetencje kulturowe czytelnika - znajomość tematu poruszanego w tekście, doświadczenie i dotychczasowa wiedza, cechy osobowości, a więc m.in. zachowania towarzyszące lekturze, ewentualne dysfunkcje, jak np. wada wzroku).

Już na podstawie wymienionych współczynników wyraźnie widać, że proces czytania jest bardzo skomplikowany. W związku z tym, tworząc komunikat typograficzny, zawsze należy rozważyć jak najwięcej elementów determinujących jego jakość (należy uwzględnić możliwie najwięcej kwestii w odniesieniu do skutku, jaki ma osiąnąć komunikat). Zespoły projektowe - w zależności od celu przekazu, możliwych warunków i sytuacji jego odbioru - są w stanie odpowiedzieć na szereg pytań odnoszących się do komunikatu oraz kontekstu jego odbioru. Ważne jest zatem całościowe, czasami nawet systemowe podejście (np. seria wydawnicza), które wiąże się ze ścisłą współpracą interdyscyplinarnego zespołu, w równym stopniu skoncentrowanego na celu tworzonego przekazu. Tym bardziej że punkt krytyczny w procesie zrozumienia treści komunikatu znajduje się zawsze po stronie czytelnika:

Książka może mieć różnych czytelników. Jedni po przeczytaniu szybko o niej zapominają. Dla innych „substancja” tej samej książki staje się ich własną substancją przekształconej świadomości czytelnika. To przekształcenie świadomości odbywa się drogą zmuszania się odbiorcy do intelektualnego wysiłku, do współuczestnictwa w rozwiązywaniu zadań, jakie przed odbiorcą stawia autor. W tym współuczestnictwie czytelnik staje się w pewnym sensie współtwórcą komunikatu [...]. Komunikat bowiem jest nie tylko faktem, lecz aktem komunikacji. Komunikat książkowy to nie tylko to, co twórca napisał, lecz i to, co z niego wyczytano ${ }^{14}$.

W tym kontekście logicznie uzasadniona wydaje się próba redefinicji typografii. Można więc przyjąć, że typografia to projektowanie komunikatów wizualnych, których celem jest ułatwienie procesu recepcji i zrozumienia tekstu (czy- tania*). W praktyce działania typografa sprowadzają się do projektowania doświadczenia czytania - rozwiązania opartego na dotychczasowych doświadczeniach użytkownika, czyli wpływania na obecne doświadczenie przez sumę wcześniejszych doświadczeń bądź też stworzenia zupełnie nowej formy doświadczania. Wymienione „doświadczenie” to m.in. komfort przyswajania tekstu (ang. readability) ${ }^{15}$, który musi być za każdym razem zdefiniowany i finalnie zapewniony przez zespół pracujący nad projektem.

Przykładem komunikatu typograficznego, konstruowanego na podstawie powyższej tezy, jest projekt skryptu skierowanego do studentów prawa, zawierającego zbiór kazusów do rozwiązania wraz z odpowiedziami (rozwiązywanie kazusów to jedno z fundamentalnych form kształcenia adeptów prawa, polega ono na analizowaniu i zrozumieniu opisanego przypadku oraz właściwym stosowaniu przepisów prawa karnego). Powstająca publikacja jest odpowiedzią na realną - dostrzeżoną przez wykładowców - potrzebę, jaką jest pomoc przyszłym

prawnikom w rozstrzyganiu zagadnień z obprawnikom w rozstrzyganiu zagadnień z o
szaru prawa karnego. W tym celu autorzy publikacji ${ }^{16}$ zdecydowali się odejść od tradycyjnego w polskim szkolnictwie prawnym systemu rozwiązywania kazusów.

Stworzono pytania i odpowiedzi drugiego i trzeciego rzędu, a także listę pytań kontrolnych, przypadki do analizy przedstawiono natomiast w formie komiksu. Co równie istotne, scenariusze komiksów nie mają ułatwiać studentom zadania i jednoznacznie sugerować odpowiedź, raczej zmobilizować do wnikliwej analizy. Partie dialogowe są napisane językiem potocznym, we wszystkich przypadkach występuje ten sam główny bohater, akcja dzieje się zaś w tym samym miejscu - nad jeziorem. Zadaniem projektantów ${ }^{17}$ było z kolei wypracowanie rozwiązania, które względnie ograniczałoby możliwości zbyt szybkiego znalezienia rozwiązania kazusu. Celem tej koncepcji jest skłonienie czytelnika do uważnej lektury, zrozumienia treści i odszukania właściwej odpowiedzi na podstawie logicznego rozumowania. $\mathrm{Z}$ tego powodu odpowiedzi zawarto na kolejnej rozkładówce, a umieszczone wśród nich, kluczowe dla kazusu kadry z komiksu mają tworzyć referencje i uzasadnić rozwiązanie. Warto nadmienić, że struktura tekstu jest bardzo bogata (wyróżnienia, tabele, tekst ciągły, przypisy, tytularia), w związku z czym hierarchia informacji musi być logiczna i konsekwentna w całej publikacji, musi tworzyć kod czytelny w każdym przypadku. Zastosowany język wizualny, w tym środki i parametry typograficzne, jest swobodniejszy w formie niż w typowych publikacjach prawniczych, z którymi studenci mają kontakt 
podczas studiów; ma to służyć lepszej interakcji czytelnika z treścią i ułatwić mu skoncentrowanie się na zadaniu. Projektowana publikacja to doskonały przykład całościowego podejścia do rozwiązywania problemu projektowego oraz projektowania wyraźnie zdefiniowanego doświadczenia; wszystkie te działania dokonywały się we współpracy interdyscyplinarnej, gdzie uczestnicy zespołu (autorzy, wydawca, projektanci) koncentrowali swoje wysiłki nad znalezieniem najlepszego rozwiązania służącego skutecznej edukacji adeptów prawa (rys. 1-2).

Inne przykłady podobnego podejścia w konstruowaniu komunikatów typograficznych pochodzą z Pracowni Typografii oraz Pracowni Informacji Wizualnej w Akademii Sztuk Pięknych w Katowicach ${ }^{18}$. Pierwszy z nich polegał na opracowaniu przez studentów pierwszego roku studiów magisterskich projektu podręcznika naukowego Kultura a rozwój. Odwołując się do istniejącej już publikacji o tym samym tytule $^{19}$, adepci projektowania mieli znaleźć odpowiedź na pytanie: „Jak sprawić, żeby studenci potrafili i chcieli uczyć się z podręcznika?”. W tym celu przeanalizowano sposoby uczenia się przez osoby studiujące, jak również metody pracy z podręcznikiem przez wykładowców. Na podstawie wyciągniętych wniosków stworzono założenia do projektu nowoczesnej serii podręczników naukowych dla studentów wybranych kierunków Uniwersytetu Ekonomicznego w Krakowie. Oprócz analizy doświadczenia procesu uczenia się na studiach wyższych rozpatrywano także treści i struktury tekstów oraz obecne w publikacji komunikaty infograficzne. Studenci ASP w Katowicach wskazali na utrudnienia wpływające na jakość korzystania z podręcznika: różni odbiorcy (odbiorca nabywający wiedzę podstawową, wykładowca, odbiorca uzupełniający wiedzę, odbiorca przypadkowy), różne potrzeby odbiorców oraz różne znaczenie informacji dla słuchaczy odmiennych kierunków, autonomiczność rozdziałów (wielu autorów, mnogość stylów tekstów, publikacja jest wypadkową antologii tekstów i podręcznika). Zasugerowano zmiany odnoszące się do redakcji tekstu (m.in. wprowadzenie pytań kontrolnych na końcu rozdziałów oraz słów-kluczy, umiesz-

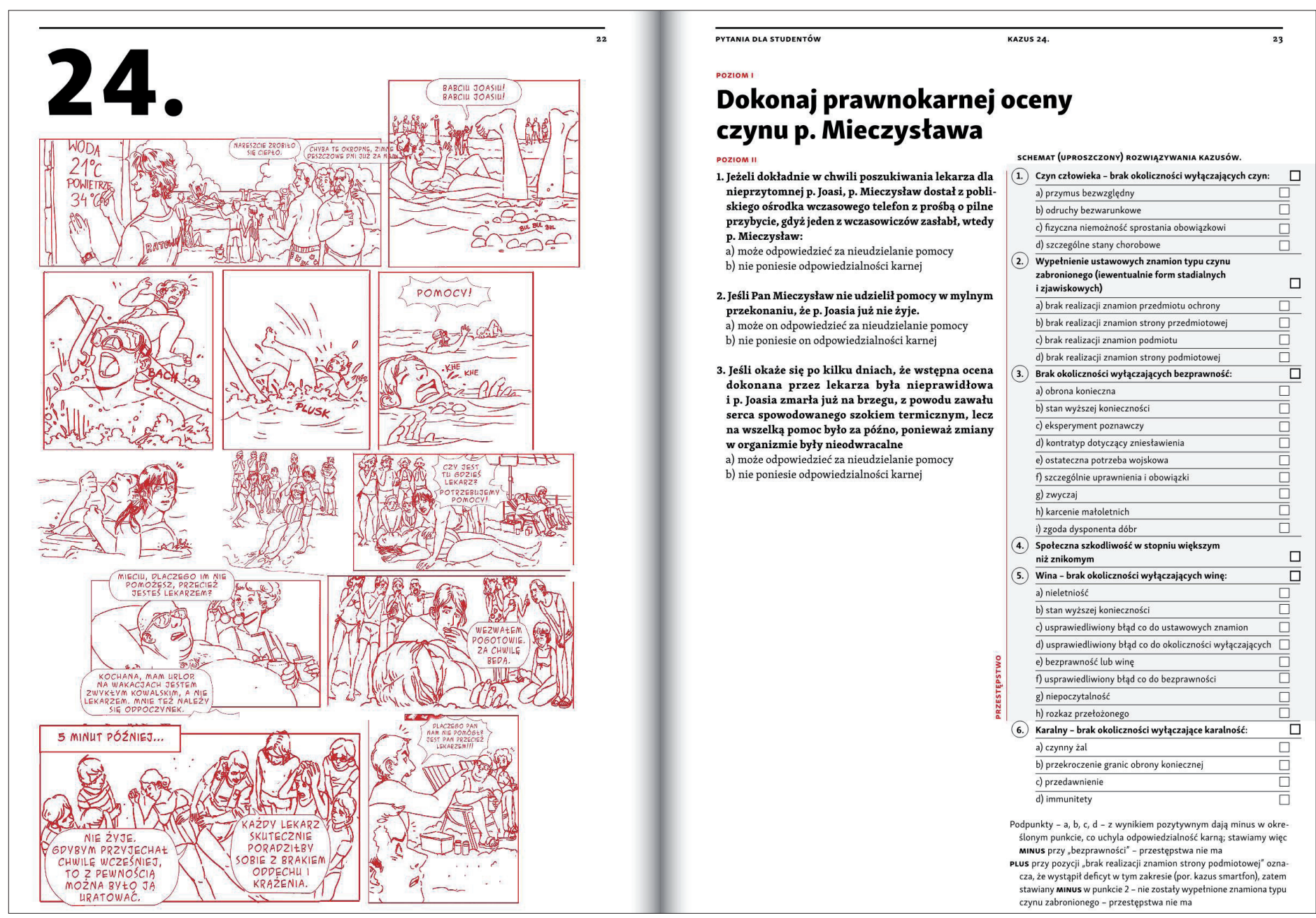

Rys. 1. Projekt skryptu skierowanego do studentów prawa 


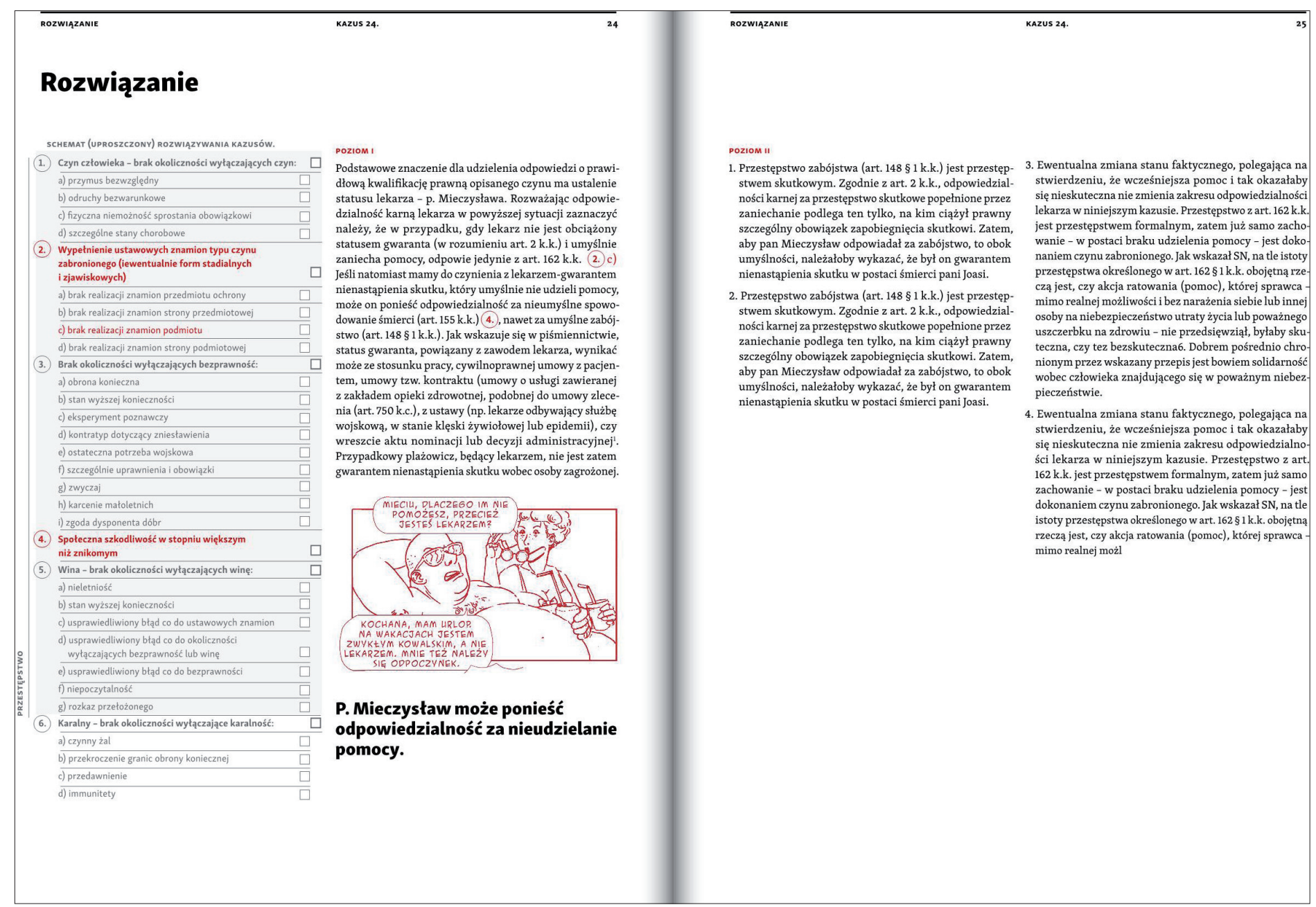

Rys. 2. Projekt skryptu skierowanego do studentów prawa

czenie tekstów o charakterze podręcznikowym, a nie stricte naukowym, ujednolicenie formalno-strukturalne rozdziałów, dodanie materiału ilustracyjnego) oraz zmiany związane z projektem (m.in. stworzenie logicznej, konsekwentnej hierarchii informacji, wykorzystanie marginaliów, wprowadzenie wyróżnień i rozróżnień dla poszczególnych części tekstów, wypracowanie poręcznego formatu i zmniejszenie wagi publikacji). Dopiero na tej podstawie stworzono nowe, systemowe rozwiązania w postaci nowej gramatyki języka wizualnego i w ten sposób zaprojektowano nową koncepcję podręcznika. Jak stwierdził prof. Jerzy Hausner, pomysłodawca współpracy między Wydziałem Projektowania ASP w Katowicach a Uniwersytetem Ekonomicznym w Krakowie, „każdy z [przedstawionych] projektów ma swoją logikę; każdy rozstrzyga problem. Projekty są próbą całościowego rozwiązania" 20 .

Kolejnym przykładem projektowania publikacji zorientowanej na użytkownika jest projekt Biblii skierowany do seniorów. Był on po raz pierwszy realizowany w ubiegłym roku przez studentów pierwszego roku studiów magisterskich w Pracowni Typografii Akademii Sztuk Pięknych w Katowicach. Studenci musieli uwzględnić m.in.: istotną dla odbiorcy treść, silną, choć nie zawsze identyczną - motywację, rodzaj lektury (np. czytanie z zainteresowaniem stałym lub zmiennym), konteksty miejsca, czasu oraz sytuacji, w których może odbywać się lektura. Ponadto, projektujący musieli wykorzystywać reguły typograficzne skierowane do osób starszych, również z dysfunkcją wzroku. Ważna okazała się także analiza struktury typograficznej i intelektualnej Biblii Tysiaclecia. Wydanie Vw Roku Jubileuszowym 2000. W tym popularnym w Polsce wydaniu Biblii wskazano na niekomfortowe warunki przyswajania tekstu w postaci: niekonsekwencji w stosowaniu niektórych środków typograficznych, nieklarownej hierarchii informacji, w końcu - nieprecyzyjnego i niekonsekwentnego umieszczania przypisów (komentarzy). Studenci musieli uwzględnić te błędy w swoich projek- 


\begin{tabular}{|c|c|}
\hline \multicolumn{2}{|l|}{ środki i parametry typograficzne } \\
\hline Księga Rodzaju & $\begin{array}{l}\text { tytuł części (księgi) } \\
\text { Adelle Sans Bold } 11 \text { pt }\end{array}$ \\
\hline DZIEJE PATRIARCHÓW IZRAELSKICH & $\begin{array}{l}\text { tytul I stopnia } \\
\text { Adelle Sans Bold } 8.9 \mathrm{pt}\end{array}$ \\
\hline Dzieje Potomków Teracha & $\begin{array}{l}\text { tytul II stopnia/podtytul } \\
\text { Adelle Sans Bold } 8.9 \mathrm{pt}\end{array}$ \\
\hline $\begin{array}{l}\text { Rodzina Abrama } \\
\text { Terach był ojcem Abrama, Nachora i Harana, a Haran } \\
\text { był ojcem Lota. } 28 \text { Haran zmarł jeszcze za życia Tera- } \\
\text { cha, swego ojca, w kraju, w którym się urodzit, w Ur } \\
\text { chaldejskim. } 29 \text { Abram i Nachor wzięli sobie żony. Imię } \\
\text { żony Abrama byłło Saraj, imię zaś żony Nachora - Milka. } \\
10 \text { Była to córka Harana, który miał jeszcze drugą cór- } \\
\text { kę imieniem Jiska. } 30 \text { Saraj była niepłodna, nie miała } \\
\text { więc potomstwa. }\end{array}$ & $\begin{array}{l}\text { tekst ciaggty } \\
\text { Adelle Serif Regular } 8.9 \mathrm{pt} / 13.6 \mathrm{pt} \\
\text { oznaczenia wersetów } \\
\text { Adelle Sans Semibold } 8.9 \mathrm{pt} / 13.6 \mathrm{pt} \\
\text { oznaczenia rozdziałów } \\
\text { Adelle Sans Bold } 12 \mathrm{pt} / 13.6 \mathrm{pt}\end{array}$ \\
\hline $\begin{array}{l}13 \text { Misrai nn aial jako potomstwo: Ludim, Anamim, } \\
\text { Lehabim, Naftuchim, } 14 \text { Patrusim i Kasluchim, od któ- } \\
\text { rych pochodzą Filistyni i Kaftoryci. }\end{array}$ & $\begin{array}{l}\text { odnośniki do przypisów } \\
\text { Adelle Sans Bold } 8.9 \text { pt (frakcja górna) }\end{array}$ \\
\hline $\begin{array}{l}\text { G Rdz 10,1 Wykaz ludów ma rozpowszechnioną u Semitów } \\
\text { formę rodowodu, którego nie trzeba brać dosłownie. Jest to } \\
\text { raczej opis stosunków ludnościowych w pewnej epoce na Bli- } \\
\text { skim Wschodzie. Idea religijna jest ta:ludzkość poprzez Noego } \\
\text { pochodzi od pierwszej pary, stworzonej przez Boga na Jego } \\
\text { obraz. W tablicy ludów nazwy etniczne wystẹpują̧ często jako } \\
\text { imiona własne protoplastów. }\end{array}$ & $\begin{array}{l}\text { oznaczenia literowe } \\
\text { Adelle Sans Bold } 7.8 \mathrm{pt} \\
\text { sigla } \\
\text { Adelle Sans Semibold } 7.8 \mathrm{pt} \\
\text { tekst przypisów } \\
\text { Adelle Regular } 7.8 \mathrm{pt} / 12.6 \mathrm{pt}\end{array}$ \\
\hline $\begin{array}{l}\text { Ksiegga Rodzaju Rdz } \\
10\end{array}$ & $\begin{array}{l}\text { żywa pagina, paginacja } \\
\text { Adelle Sans Regular } 7.8 \mathrm{pt}\end{array}$ \\
\hline & $\begin{array}{l}\text { linie oddzielające tekst ciągły od przypisów dolnych } \\
0.35 \mathrm{pt}\end{array}$ \\
\hline
\end{tabular}

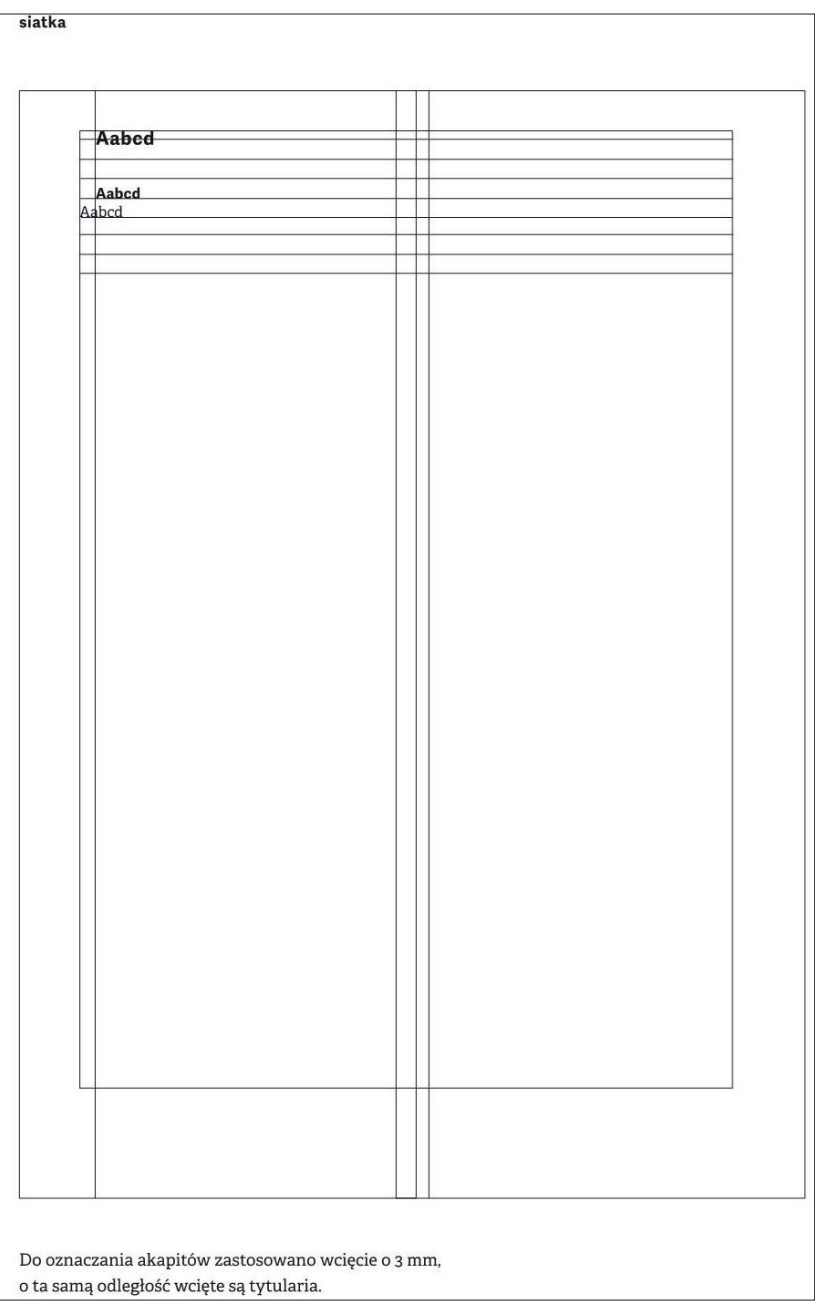

Rys. 3. Projekt Biblii skierowany do seniorów

tach i wypracować optymalne rozwiązanie. Na tej podstawie zdefiniowano założenia projektowe i dopiero wtedy stworzono koncepcje publikacji Biblii dla osób starszych. Na koniec powstały towarzyszące projektom dokumentacje, w których znalazły się opisy poszczególnych etapów pracy i rozwiązania, w postaci wskazania środków i parametrów typograficznych, wybranej kolorystyki, formatu, layoutu, rodzaju papieru i oprawy. Opisano także cel publikacji, sprecyzowano odbiorcę i zdefiniowano problem projektowy (rys. 3).

Key Words: typography projects, redefining typography, design, phenomenon of reading, the new way of creating messages

Abstract: The article describes examples of typography projects created from the author' own scientific experience and teaching. As demonstrated we can say that even when using ideas far away from traditional ones the ultimate aim is still achievable. What is worth to indicate is that mentioned concept comes from, not entirely revealed, phenomenon of reading and not from, so-called "output philosophy". The main bullet of the design is based on having a user inside the circle of this process. Of course everything might change and becomes a subject to modification however the fundamental concept should stay the same that means keeping a high quality of the remittance.

1G. Unger, Kiedy czytamy, w: Widzieć. Wiedzieć. Wybór naiważniejszych tekstów o dizajnie, pod red. P. Dębowskiego i J. Mrowczyka, Kraków 2011, s. 171.

${ }^{2}$ Andrew Piper udowadnia, że dyskusje dotyczące końca czytelnictwa, upadku książki, zastapienia starego medium nowym odbywały się już kilkaset lat temu. Wszystko, o czym się mówi na ten temat i czyta online, zostało już niejednokrotnie powiedziane w przeszłości; A. Piper, Book Was There, Chicago-London 2012, s. IX.

${ }^{3}$ N. Carr, Płytki umyst. Jak internet wpływa na nasz mózg, Gliwice 2013, s. 243.

${ }^{4}$ M. Tabaczyński, Wstęp, w. J. D. Bolter, Przestrzeń pisma. Komputery, hipertekst i remediacja druku, Kraków-Bydgoszcz 2014, s. 9

${ }^{5}$ A. Pawłowski, Inicjacje. O sztuce, projektowaniu i kształceniu projektantów; cyt. za: J. Ginalski, M. Liskiewicz, J. Seweryn, Rozwój nowego produktu, Kraków 1994, s. 56.

${ }^{6} \mathrm{Ibidem}, \mathrm{s.} 9$.

${ }^{7}$ S. Sierwiotyński, Zadania nauki o książce; cyt. za: T. Zbierski, Semiotyka książi, Wrocław 1978, s. 93.

${ }^{8} \mathrm{Ibidem}, \mathrm{s} .18$. 


\section{Tomasz Bierkowski}

9 "Jeżeli potrafimy coś nazwać, możemy to poprawić. Jeżeli wyznaczymy cel, mamy większe szanse go zrealizować lub zbliżyć się do niego" (dr hab. Andrzej Sobaś, projektant, wykładowca ASP w Katowicach, w prywatnej korespondencji z autorem z 23 stycznia 2012 roku)

${ }^{10}$ T. Zbierski, op. cit., s. 29

Warto nadmienić, że to nie wybór medium decyduje o tym, czy narracja jest linearna, czy asocjacyina. Na przykład w przypadku klasycznego podręcznika mamy do czynienia z narracją asocjacyjną. Tekst prozatorski w postaci e-booka to z kolei narracja linearna. 0 rodzaju interakcji i sposobie lektury rozstrzyga nie medium (ono daje jedynie możliwości, narzędzia), ale rodzaj tekstu i projekt.

Teodor Zbierski dzieli odbiorców (czytelników) na trzy grupy: odbiorca-czytelnik potencjalny, który potrzebuje książki, odbiorca-czytelnik konsumpcyjny, który jest zaspokojony otrzymaną książką, odbiorca-czytelnik produkcyjny, użytkujący książkę w dalszym procesie produkcyjnym; T. Zbierski, op. cit., s. 15.

Dojrzałość emocjonalna z cała pewnościa wpływa na percepcję i rozumienie tekstu. Nie jest natomiast cechą osobowości [...], to raczej stan osobowości, która może dojrzeć (zatem ma w sobie potencjał rozwojowy). Cechy osobowości to na przykład elastyczność, otwartość, intro/ekstrawersja, stałość (cierpliwość), uważność, otwartość, ciekawość" (dr nauk med. Helena Zakliczyńska w prywatnej korespondencji z autorem 20 stycznia 2016 roku).

${ }^{14}$ T. Zbierski, op. cit., s. 29

Readability - miara tego, na ile dany tekst dostarcza łatwej i przyjemnej lektury; J. Felici, Kompletny przewodnik po typografii. Zasady doskonałego składania tekstu, Gdańsk 2006, s. 332

${ }^{16}$ Dr Olga Sitarz, wykładowca na Wydziale Prawa i Administracii Uniwersytetu Śląskiego w Katowicach, oraz Andrzej Wiencek, prezes wydawnictwa Od.Nowa, specjalizującego się w publikacjach prawniczych.

${ }^{17}$ Projektantami zbioru kazusów są Martyna Bargiel oraz Tomasz Bierkowski.

${ }^{18}$ Projekty realizowane pod kierunkiem dr. hab. Jacka Mrowczyka (Pracownia Informacji Wizualnej) oraz dr. hab. Tomasza Bierkowskiego (Pracownia Typografii).

${ }^{19}$ Kultura a rozwój, pod red. J. Hausnera, A. Karwińskiej i J. Purchly, Kraków 2014.

${ }^{20}$ Prof. Jerzy Hausner na spotkaniu z zespołem autorów, redaktorów oraz przedstawicieli ASP w Katowicach, Kraków.

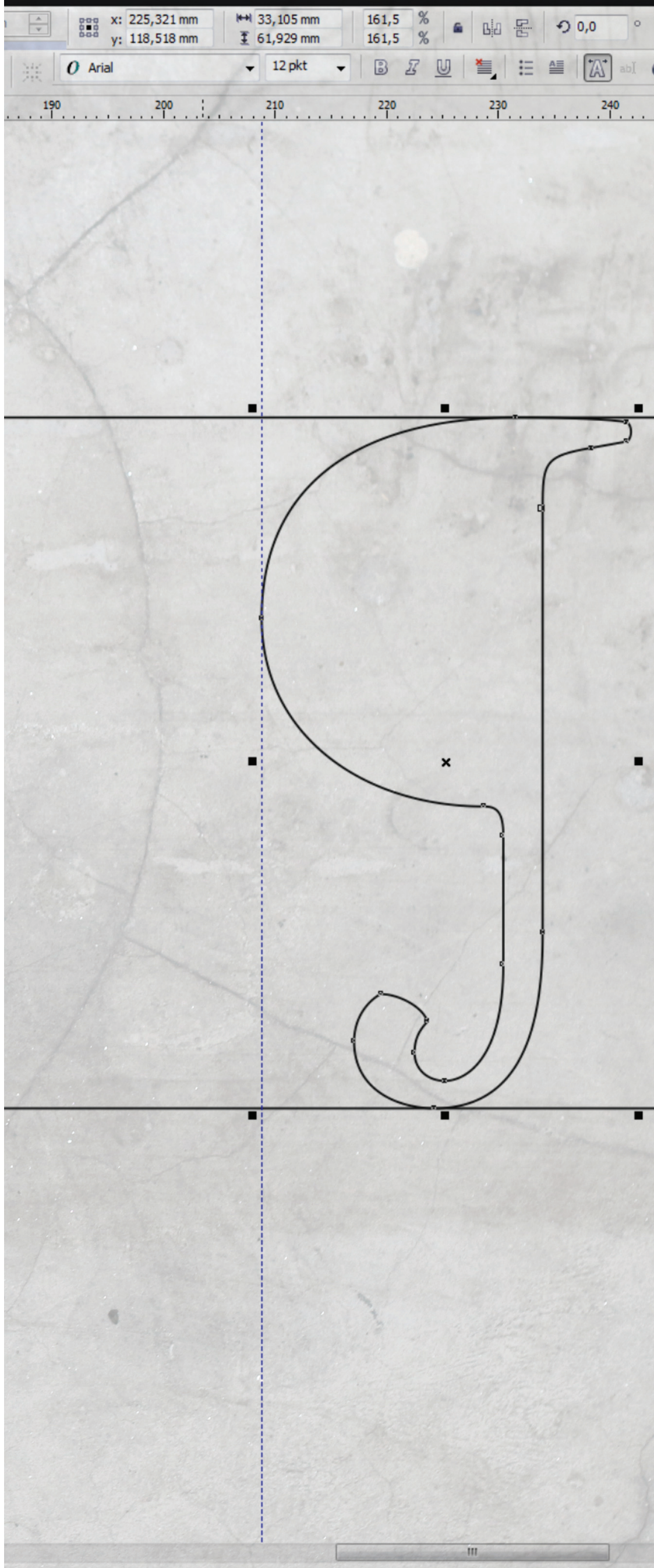

